\title{
TEACHER EDUCATION IN ENGLAND
}

A CRITICAL INTERROGATION OF SCHOOL-LED TRAINING

\section{Tony Brown}


'This book provides a riveting but deeply disturbing account of how initial teacher education in England has been overturned and reshaped over recent years. In spite of the huge commitment of those teachers and university staff involved in the processes of preparing future teachers, the evidence in this book reveals the unsettling and disruptive effects of many aspects of radical government intervention. Although the main focus of the book is on England, Tony Brown skillfully uses international perspectives to identify wider trends as well as to characterise the peculiarities of the English. This book adds enormously to our understanding of what has been happening in teacher education and through the judicious use of extracts from research interviews it brings to life the real world of beginning teachers and those who support them.'

-Ian Menter, Emeritus Professor of Teacher Education, University of Oxford, UK

'This book records and analyses many failures of contemporary teacher education policy in England. It is evident that short-termist, marketised manipulation cannot guarantee the quality or supply of teachers which the nation needs. More stable, educationally principled approaches, based on respect for teacher expertise and constructive partnerships between schools and universities, are clearly called for. But will they be forthcoming?’

-Andrew Pollard, Professor of Policy and Practice in Education, University College London, Institute of Education 
$\because$ Taylor \& Francis

Taylor \& Francis Group

http://taylorandfrancis.com 


\section{Teacher Education in England}

Models of teacher education in England have undergone major upheaval in recent years. Teacher Education in England draws on the experiences of some of the people directly involved in these changes and explores the implications that they have had on their professional lives. The book also explores the challenges faced by universities in responding to the ascendance of school-led teacher training and the ways in which this impacts on conceptions of teacher education more generally, in England and beyond.

Drawing on 150 interviews with teacher educators and trainees, this book documents how the systemic changes to teacher education have been implemented, and explores the impact of these changes on the people directly affected by them. Presenting insider accounts, the book shows that structural adjustments have impacted on many dimensions of teacher education that had characterised university input and have also unsettled more familiar understandings of professional identity and staffing composition. Demonstrating that the redistribution of teacher education across new apparatuses bolsters market forces, whilst maintaining the option of creating new forms of training that transcend established boundaries, Brown also explores the opportunities that are opened up by the new models.

Teacher Education in England is the first substantial study to focus on School Direct since its implementation in 2013. As such, the book should be of great interest to academics, researchers and postgraduate students engaged in the study of teacher education and educational policy. It should also be essential reading for teacher educators, as well as for teachers and trainee teachers.

Tony Brown is Professor of Mathematics Education at Manchester Metropolitan University. 


\section{Routledge Research in Teacher Education}

For a full list of titles in this series, please visit www.routledge.com

The Routledge Research in Teacher Education series presents the latest research on Teacher Education and also provides a forum to discuss the latest practices and challenges in the field.

Books in the series include:

Learning to Teach in England and the United States

The Evolution of Policy and Practice

Maria Teresa Tatto, Katharine Burn, Ian Menter, Trevor Mutton

and Ian Thompson

Teacher Education in England

A Critical Interrogation of School-led Training

Tony Brown

Preparing Classroom Teachers to Succeed with Second Language Learners Lessons from a Faculty Learning Community

Edited by Thomas H. Levine, Elizabeth R. Howard, and David M. Moss

Interculturalization and Teacher Education

Theory to Practice

Cheryl A. Hunter, Donna K. Pearson and A. Renee Gutiérrez

Community Fieldwork in Teacher Education

Theory and Practice

Heidi L. Hallman and Melanie N. Burdick

Portrait of a Moral Agent Teacher

Teaching Morally and Teaching Morality

Gillian R. Rosenberg

Observing Teacher Identities Through Video Analysis

Practice and Implications

Amy Vetter and Melissa Schieble 


\section{Teacher Education in England}

A Critical Interrogation of School-led Training

\section{Tony Brown}


First published 2018

by Routledge

2 Park Square, Milton Park, Abingdon, Oxon OXI4 4RN

and by Routledge

711 Third Avenue, New York, NY 10017

Routledge is an imprint of the Taylor \& Francis Group, an informa business

(C) 2018 Tony Brown

The right of Tony Brown to be identified as author of this work has been asserted by him in accordance with sections 77 and 78 of the Copyright, Designs and Patents Act 1988.

All rights reserved. No part of this book may be reprinted or reproduced or utilised in any form or by any electronic, mechanical, or other means, now known or hereafter invented, including photocopying and recording, or in any information storage or retrieval system, without permission in writing from the publishers.

Trademark notice: Product or corporate names may be trademarks or registered trademarks, and are used only for identification and explanation without intent to infringe.

British Library Cataloguing-in-Publication Data

A catalogue record for this book is available from the British Library

Library of Congress Cataloging-in-Publication Data

A catalog record for this book has been requested

ISBN: 978-1-138-30766-7 (hbk)

ISBN: 978-1-315-14244-9 (ebk)

Typeset in Galliard

by Apex CoVantage, LLC 


\section{Contents}

Foreword

viii

Acknowledgements xi

About the author xiii

Preface xiv

1 Introduction 1

2 School-led training in England (with Harriet Rowley and Kim Smith)

3 Research-in teacher education 44

4 Shifting under-sandings of subject knowledge $\quad 57$

5 Summing up mathematics subject knowledge $\quad 70$

6 Theoretical becoming as a teacher $\quad 87$

7 Evolving teacher educator responsiveness 102

8 Conclusion 118

References $\quad 130$

Index 143 


\section{Foreword}

It is an honour to be invited to contribute a foreword to such a forensic examination of the current state of teacher education in England.

Professor Brown demonstrates a passion for the subject that focusses on the need for those entering the teaching profession to have the best possible vocational preparation, and his deep concern at recent developments permeates this book.

I share the basic premise of his analysis: that the distinctive and long-established role for university teacher education has been weakened to the point that serious questions are raised about the very purpose of teaching. As the parent of a child at a maintained primary school, I believe I have the right to expect that those entrusted on a day-to-day basis with ensuring that my son's development is stretched to the limit of his capabilities have themselves been subject to a rigorous grounding in both the theory and the practice of pedagogy. Not just what works, but why it works.

The pre-eminence given to the school-led models compromises understandings of what we are trying to achieve as a country. This means the market deciding, rather than educational principles. We can aspire to a more collective vision.

It is much to be regretted that teacher education appears not to be sufficiently valued for its own worth by those whose task it is to shape education in its broadest sense. At the 2017 general election, none of the three main political parties mentioned teacher education in their manifestos. The fact that the current party of government now prefers the term 'teacher training' is surely instructive.

Those words were prominent in the white paper 'Educational Excellence Everywhere', published in March 2016, which proposed inter alia to replace Qualified Teacher Status with a form of accreditation. A subsequent change of Secretary of State for Education was welcome, not least because she declared,

A mature profession needs a high status qualification that reflects the standards. Some people have suggested QTS might be scrapped or replaced by some vague notion of accreditation. I want to be absolutely clear on that, not on my watch.

Her watch survived the general election but few regard the issue as settled and the case for a high-status qualification must be argued for relentlessly to ensure it is not eroded. 
I do not advocate a single route into teaching. School Direct and the SchoolCentred Initial Teacher Training programme certainly have a role to play, but both should be based on a partnership between schools and universities, each playing a complementary role to achieve the breadth necessary within teacher education.

Placing the emphasis on subject knowledge affects that balance, tilting it away from pedagogy and related important areas of study like child development, psychology, sociology and the philosophy of education. The impact on Higher Education Institutions (HEIs) and schools of education has already been profound, even on previously strong and successful institutions. HEIs equip new teachers with new knowledge and access to research on teaching and learning; teachers read more extensively during initial teacher education (ITE) than at any point in their career. Evidence from overseas indicates that effective ITE depends on close relationships between HEIs and schools. Neither can work successfully without the other.

Yet the Department for Education (DfE) prefers a supply model that takes no account of regional differences. Terms such as 'school-led' and 'universityled' are unhelpful because they fail to reflect the realities of teacher education. Universities and schools have developed strong relationships over many years, becoming exemplars of good practice. Neither the need nor the political imperative to break those links exists, yet the introduction of market forces sees universities competing more directly with each other, as well as with the disproportionate share of resources - and student places - channelled to schools.

Increasingly, achieving Qualified Teacher Status (QTS) is not regarded as essential. Since 2012, academies have been allowed to engage unqualified teaching staff and many now do so. Teaching is a graduate profession and there needs to be a clear, objective point of entry. Removing the requirement for QTS devalues those with existing qualifications and can undermine morale within the profession.

The importance of morale in teaching should not be underestimated. The interviews that Professor Brown undertook with teacher educators and established teachers who had completed doctoral studies alongside their teaching duties demonstrate that such activity was neither encouraged by head teachers nor valued by Ofsted. This state of affairs was viewed with disdain by teacher educators and teachers, who believe the analytical skills acquired through the process of external study enabled them to question and think through changing demands and identify those which provided an opportunity for development. In one case highlighted, a teacher educator had taken a pay-cut, working four days a week to complete her PhD.

Such anecdotal evidence of the conflicting pressures facing teachers is itself a matter for concern, yet no more so than the fact that of those who qualified in $2011,31 \%$ had left the profession within five years of becoming teachers. Excessive workload was the most common factor cited, but the emphasis on teacher performance was another. Non-stop testing is bad for children, but non-stop surveillance, monitoring and judging of teacher performance is detrimental to teaching, as it prioritises style over substance. 


\section{$\mathrm{x}$ Foreword}

Yet there is scant evidence that within the DfE either officials or their ministers are sympathetic to the underlying causes of the problems associated with teacher recruitment and retention.

As a politician - albeit without access to the levers of power - to an extent I share responsibility for that failing, characterised by a lack of sufficiently robust questioning of the factors underpinning the current direction of travel of teacher education. I intend on using the powerful arguments advanced in this book to inform the development of policy within my own party.

England's future teachers require both practical classroom experience and the space within that environment to reflect critically on their developing practice, learning from emerging research evidence. Professor Brown's arguments make that case convincingly. When someone of his experience offers such a well-researched and well-structured critique of teacher education today, then educationists and the politicians who guide teachers should take notice. And then take action.

Mike Watson

(Lord Watson of Invergowrie)

Labour Party Shadow Education Minister

House of Lords 


\section{Acknowledgements}

This book is centred on work arising from two empirical projects carried out over the period 2010-2016, where each project was concerned with investigating and describing a specific model of school-based teacher training. I worked on both projects with my colleague Dr Kim Smith, who first invited me to work with her and her teaching partner Elaine Hodson as they carried out practitioner research into their own teaching on what was called the Graduate Teacher Programme (GTP). Kim must take credit in enabling all of what follows. The GTP was an experiment in reducing the university component of training to no more than ten days and had grand ambitions in which student teachers would be paid and then assured of a job in their training school. This work led to papers in Journal of Education for Teachers, Teachers and Teaching, Educational Action Research and Mathematics Education Research Journal. The success of this first project led to the recruitment of a research assistant to work with Kim and me for a more sustained second project focusing on the newly and widely introduced School Direct programme. We were very fortunate to appoint Dr Harriet Rowley, who then worked with us for two years. We are grateful to the large number of people who agreed to be interviewed by Harriet and/or myself. Together we presented the findings at many conferences. This part of the project led to co-authored open access papers in the British Journal of Educational Studies and the British Education Research Journal. I am grateful to the journals mentioned above for allowing the reproduction of some material, and to Sage for permission to use some material from a chapter published in the Sage International Handbook of Teacher Education. The final report now modified for this book was kindly circulated by several organisations, including British Education Research Association, Universities Council for the Education of Teachers, Association of Mathematics Education Teachers and British Society of Research into Learning Mathematics. Research Intelligence, Schoolsweek, Teachwire and the Times Education Supplement also featured the project. It was our good fortune that Trevor Fisher of the Symposium of Sustainable Schools invited us to present the report at a parliamentary seminar at the House of Lords attended by the shadow education team. We are indebted to Lord Watson of Invergowrie for facilitating this event, and to Jeff Smith MP for his help. Thanks also go to Professors Margaret Walshaw and Nesta Devine, who enabled the research to be extended to New Zealand, with fifteen 


\section{xii Acknowledgements}

teacher educators kindly agreeing to be interviewed. Hauke Straehler Pohl, Paivi Portankorva Koivisto and Nati Adamuz provided invaluable information about their countries. Many colleagues at Manchester Metropolitan University have provided sustained support over the years, especially the members of the Building Research into Teacher Education group. Chris Hanley has made it possible for the work to reach into the future through exploring new avenues in teacher education in secondary English, introduced in Chapter Four here. That work has featured in Journal for Curriculum Studies, Discourse, and Educational Philosophy and Theory. I must also mention some people who read the draft of the book and offered many helpful comments: Margaret Walshaw, Phillip Bamber, Snezana Lawrence, Kathy Nolan, Dalene Swanson, Chris Hanley and Mike Dore.

And finally, love to my family, Alison, Elliot and Imogen.

Tony Brown June 2017 


\section{About the author}

Tony Brown is Professor of Mathematics Education at Manchester Metropolitan University. His work is primarily concerned with considering mathematics education and teacher education through the lens of contemporary social theory. He has written seven previous books and many journal articles in these areas. Tony has also had a long-standing interest in professionally oriented research, typically carried out by practitioners working on doctoral studies. His own students have researched areas as diverse as science education, mathematics education, teacher education, emergency medicine, police training, emotion in special needs education, educational links with industry, English education, race and ethnicity, popular music education, global education in development contexts, early-years education, school leadership, and digital media. Seven of these doctoral projects have led to book publications. Tony co-organised the conferences on Mathematics Education and Contemporary Theory, held at MMU in 2011, 2013 and 2016 and co-edited special issues of Educational Studies in Mathematics from material that arose.

Originally from London, Tony Brown trained in Canterbury and Exeter before returning to central London, where he taught mathematics for three years at Holland Park School. The next three years were spent as a mathematics teacher educator for Volunteer Services Overseas in Dominica in the Caribbean. In 1987, he completed his $\mathrm{PhD}$ at Southampton University, which focused on language usage in mathematics classrooms, based on data collected in Dominica and London. After a spell as the mathematics coordinator in a middle school in the Isle of Wight, Tony moved to Manchester Metropolitan University (then polytechnic) in 1989, where he became a professor in 2000. During 2003 and 2004 Tony was based at the University of Waikato, where he was the first Professor of Mathematics Education in New Zealand. 


\section{Preface}

The 2016 Education White Paper Education Excellence Everywhere (a key government policy document) announced changes which have perplexed many involved in teacher education inside and outside universities. Government plans are directed at school education but have a profound relevance for university education more generally. There is a direct threat to higher education from the proposals to further reduce the role of universities in Initial Teacher Education. For higher education, as a whole, the plan to intensify the current system of on-the-job training for teachers located at school level poses threats to subject knowledge and teacher skills. If the plans are approved by parliament, it is likely that schools will not have enough teachers with the skills to prepare students for university courses. Both the Commons Public Accounts Committee and the Education Select Committee have taken a close interest in teacher training and supply in recent months.

These concerns prompted a parliamentary seminar at the House of Lords in London, initiated by the Symposium on Sustainable Schools, and chaired by Lord Watson of Invergowrie. The speakers included Alison Ryan of the Association of Teachers and Lecturers, Professor Tony Brown of Manchester Metropolitan University and Dr Sue Pope, also of MMU, representing the Association of Teachers of Mathematics.

The direction of travel for teacher training in England since the Cameron Conservatives took office in 2010 has been to invest in "school-led training" rather than university-based teacher education. A simple pattern of university or schoolbased teacher education has never existed - the two have traditionally been in partnership but the involvement of schools has increased over recent decades. This trend has been divergent with other European countries and increasingly with other parts of the British Isles. More recently, schemes like School Direct and its New Labour forerunner, Teach First, (Britain's answer to Teach for America) have been in the ascendance. The latter scheme takes high-performing graduates and puts them on a fast-track, high-cost, school-based training programme, but with some university input. Teach First, however, has only a small allocation, comprising $5 \%$ of training places, and many such trainees leave the profession within a few years. School Direct, started in Michael Gove's era at the DfE, has mushroomed and now (2016) provides some $50 \%$ of trainee places, and 
has led to the closure of some university education departments. School Direct comprises a one-year school-led postgraduate course where students often spend as little as 30 days in university. Currently, all forms of teacher training lead to Qualified Teacher Status (QTS), which, like the one-year Postgraduate Certificate of Education (PGCE), is internationally valued. Yet the White Paper is proposing to replace QTS with an accreditation process spanning the first few years of teaching. These proposals also include expanding the role of School-Centred Initial Teacher Training, currently accounting for $7 \%$ of training provision, where no university input is required.

There is a marked lack of evaluation of these changes, with few independent studies. A recent report on School Direct by a team at Manchester Metropolitan University, led by Professor Tony Brown, argued that with new models of training, local market conditions rather than educational principles can determine the design of training models and how the composition of teacher preparation is shared across school and university sites. The content and structure of School Direct courses varies greatly between different partnership arrangements across the country, leading to greater fragmentation within the system as a whole. There is not only increased diversification in terms of types of training route available but also differences of experience within any given route. School Direct has also altered the balance of power between universities and schools, and in turn their relationships with one another and how the responsibilities of each party are decided. Furthermore, those in different locations negotiating territorial boundaries can activate anxiety and tension across school-university partnership arrangements. This has particular impact on different school subjects as schools and universities often have contrasting approaches to how they are taught.

The plans proposed in the White Paper go further than School Direct and involve abolishing QTS. The plan is to impose an accreditation model overseen by Teaching Schools - though there will be some role for unspecified elite universities. There is a lack of detail on accreditation (para 2.31), but government plans to abolish the tried and tested Qualified Teacher Status are explicit (para $2.41)$ though detail is again lacking. The model envisaged is essentially that the trainee will work in a single school and evaluated by a head teacher or other internal school appointee. The only specific example given of the model (p. 34) has a higher education-free system, though the trainee has a degree which gives subject knowledge. For primary-school teachers, the degree of subject knowledge required has traditionally been less than that of a degree, but there are already issues with lack of subject knowledge at primary level even while university involvement remains in place.

Concern is growing over limited subject knowledge in teachers new to the classroom. School Direct has been criticised for inadequate preparation both in pedagogy and subject knowledge. The Public Accounts Committee (PAC) report of 2016 was concerned that growing numbers of teachers had no subjectrelevant post A-Level qualification (high school), something that must impact on preparation for university level education. An Education Select Committee hearing was told by Professor Jane Courtney of the Deans of Education network 
at Million Plus Universities that in primary schools, because subject training in universities is now so marginal, "we could be sending people out with as little as three hour taught input in a subject like PE". ${ }^{1}$ For those training in schools little more may be done than enable teachers to work through commercial schemes as implementers of curriculum, as opposed to other EU students following university-intensive courses where relatively low attention is given to the practical school aspects during the university element.

The government fails to acknowledge that the new systems simply do not provide enough teachers in their current form. Universities and College Union, in its parliamentary briefing (May 2016) noted that the National Audit Office recorded that universities filled $85 \%$ of their places, School-Centred Training Initiative Providers (SCITTs) 65\% and School Direct 58\%. Though overall targets for recruitment have been missed for four years, the Department for Education and its political masters fail to accept that shortfalls occur in the school-based programmes, and continues to press for school-based Initial Teacher Training (ITT) through the White Paper. Most ominously, the chair of the PAC, Meg Hillier, noted that "the Department for Education has . . remained woefully aloof from concerns raised by frontline staff and freely available evidence". This is undeniable, and points up the contrast between the "evidence based practice that the White Paper claims will be the hallmark of the proposed new system, and the Department for Education's (DfE) own practice within a politically driven reform process".

Tony Brown and Trevor Fisher (Symposium on Sustainable Schools)

This preface first appeared as a short article entitled, "A white paper demanding scrutiny" in Research Intelligence, a discussion journal of the British Educational Research Association, summer 2016, pp. 9-10.

\section{Note}

I BBC news report, www.bbc.co.uk/news/education-36480071 


\section{Introduction $^{1}$}

Teacher education in England is not what it used to be. Its institutions, and the people within them, have changed, both within themselves and in relation to each other. Some of the institutions have recently closed or been transformed beyond recognition. Teacher educators, often called "tutors", have also been obliged to change - maybe too quickly - as they advance through their careers, as the locations and parameters of what had been their professional life meet new demands, new understandings. Increasingly or ultimately, they make way for people formed in different circumstances, according to new values, who understand themselves in different ways.

Models of teacher education in England have undergone major upheaval in recent years, seemingly at an unprecedented rate of change. This book draws on the experiences of some of the people directly involved in these changes and the implications for their professional lives. The purpose of the book is to better understand the challenges faced by universities in responding to the ascendance of school-led teacher training and the ways in which this impacts on conceptions of what it is to become a teacher more generally, in England and beyond. The book argues that the structural adjustments have impacted on many dimensions of teacher education that had characterised university input, such as subject knowledge, conceptions of theory and inclusion of research, and unsettled more familiar understandings of professional identity and staffing composition. The book outlines the empirical results from over 150 interviews with teacher educators and trainees towards assessing the impacts of these changes. Theoretically, the book depicts the systemic operation of teacher education and its formative impact on participants.

Recent years have experienced a government-led push to relocate teacher education to schools, rename it as "teacher training", and to better understand the "customer's journey" (National College of Teaching and Leadership, 2016) into a bewildering array of options so that the conservative-led government might secure its preferences, seemingly, for increasingly privatised arrangements. After various experiments with employment-based routes, the British government has set its sights on the expansion of the one-year "School Direct" model of schoolled teacher training within England, where university services are "bought in" to meet teaching, assessment and accreditation needs. On many such routes 


\section{Introduction}

students typically spend around 30 days in university, with the remainder of time teaching in schools. A school-based mentor takes a major responsibility for the student's training. The composition of student training in these new arrangements has gone through various adjustments, such as: less subject knowledge, less generic educational studies, less access to literature and more time in schools, where time in schools is more accountable to the priorities of those schools, defined in terms of achievement of school objectives (test scores, meeting parent demands, within given budget). This reconfiguration has affected the structure, content and values within a much-changed teacher education process, quite out of line with trends on mainland Europe, where university-based courses have typically increased from four to five years, often followed by 18 months or more of school placement.

This book documents how these systemic changes have taken place, how they have impacted on the people implicated in them and how that impact has been experienced through the words of those people. Through presenting insider accounts from these people, the book will delineate the operation of "teacher education" and show how its redistribution across new apparatuses serves to shore up the market forces whilst maintaining the option of creating new forms of life that transcend more familiar boundaries. The book, however, also explores the opportunities that the new models open.

Schooling is increasingly shaped and judged by its perceived capacity to deliver success in terms of international competitiveness as measured by testing programmes such as the OECD Programme for International Student Assessment (PISA) or Trends in Mathematics and Science Study (TIMSS), which have perhaps privileged Western concerns. Governments around the world, however, have been jockeying for a better position in the resulting league tables, which are supposedly indicative of wider economic competitiveness. They have been seduced by the appeal of raising standards in a statistically defined world. And so often the job of researchers has become to take on the challenge of raising standards in line with "high-performing countries" (Darling-Hammond, 2017). What had been introduced to measure school performance now defines what it is and polices its boundaries. That is, such comparisons have transformed the content of what they compare and the demands on the teachers preparing to meet these newly defined challenges. Yet policy responses to these economic priorities and actual teacher supply have been conceptualised in diverse ways across different countries.

This book begins by examining some examples of policy initiatives in teacher education by looking at two very different responses to changing teacher preparation. In some countries, teacher education increasingly comprises a vocational employment-based model of training located primarily in schools. England is a prominent example, to be explored in detail below, with similar models being introduced in parts of New Zealand and of the United States.

In the US, the turn towards practice is strong, although it has many competing manifestations, including fast-track entry routes featuring "on-the-job" training; state requirements that teacher candidates pass a uniform teacher 
performance assessment for initial licensure; school-based residency models of teacher preparation; new "graduate schools of education" unaffiliated with universities, where the curriculum emphasises teaching techniques of "successful", university programmes that revolve around "high-leverage" classroom practices; professional requirements that stipulate that more of the overall hours of teacher preparation be spent in clinical practice; and new kinds of partnerships with communities and schools.

(Cochran-Smith, 2016, p. xiii)

This approach (for a fuller discussion of the US, see Zeichner, 2010) is in sharp contrast to models followed in continental Europe, subject to the Bologna Process, where student teachers spend much more time in university: five years in Finland, for example, where a master's degree is required. These two approaches reveal radically different conceptions of how teacher quality might be improved in the name of international competitiveness. In the first, teacher education has been wrested from its traditional home within the academy and changed so that universities play a support role to what has become "school-led" training, where the lion's share of government funds for teacher education has been diverted to schools. Teacher professional identity has been referenced to skill development within this frame and the wider assessment culture. The second model, meanwhile, is similarly concerned with "raising teacher quality . . . (but specifically) in a way which responds to the challenges of lifelong learning in a knowledge based society" (ENTEP, Dimitropoulos). It is characterised by reinvigorated faith in academic study and promotion of individual teachers, where a pedagogical dimension is included from the outset of undergraduate studies, but with relatively brief periods spent in school.

Thus, two radically alternative conceptions of teacher education have emerged in Europe, both seemingly in response to the ascendance of international comparisons as a framework of reference in deciding policies motivated by assumptions of education being linked to economic wellbeing. This first chapter briefly outlines how both models trouble common assumptions about the role of universities in teacher education and how market conditions can undermine educational principles and customary practice.

In England, atypically perhaps among other countries in Europe, if not the world, most teacher education has moved into schools, with universities playing a more peripheral role. This is ostensibly a lower-cost and more practical approach to teacher education that may ultimately appeal to other countries. This model will be the principal focus of attention seen in terms of how it affects the contribution of universities. The point of this book, however, is not to invite international readers to try this at home. The more general issue relates to how teacher education knowledge is conceptualised and how this shapes practice, but also to questioning how and why university contributions have been conceptualised in the way that they have been. This first chapter considers the choice between the benefits of school-based training and university-led teacher education. By taking a different perspective on more familiar models 


\section{Introduction}

the rationale for these models might be seen differently, whilst raising the more generic issue of how learning to teach happens differently across university and school locations.

\section{The European context}

It may be helpful to draw some preliminary comparisons with other countries in the European Union (EU) as to the number of days student primary teachers spend on "education" courses in university. The Bologna Process brings broad consistency to Initial Teacher Education (ITE) across the EU, where time in university has generally increased with England as a notable exception.

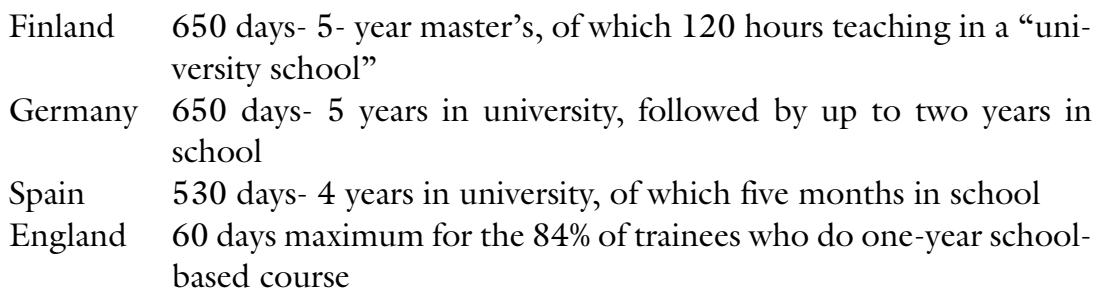

The figures for most EU countries contrast sharply with England, where students spend no more than 60 days in university. This figure is much less in most institutions, where a total of 30 days is more usual. This is the result of only $16 \%$ of all teachers doing an undergraduate course in Initial Teacher Training as followed elsewhere in the EU, whilst $84 \%$ do one-year postgraduate courses, of which $50 \%$ follow School Direct model (ref. National Audit Office, 2016). Data here is based on discussions with teacher educators in those countries. A rather more robust comparison between "high-performing countries" Australia, Canada, Finland, Shanghai and Singapore is provided by (Darling-Hammond, 2017). Another book rather rejects those sorts of comparisons within singular one-size-fits-all scales (Clarke and Phelan, 2017). Meanwhile, a further book provides an analysis of teacher education policy for the five primary jurisdictions of the British Isles and identifies England as an outlier even within that group (Beauchamp, Clarke, Hulme, Jephcote, Kennedy, Magennis, Menter, Murray, Mutton, O’Doherty and Peiser, 2016).

With rather less academic rigour, but with an exquisite twist of irony in their titles, there have been two recent government white papers specifying government intentions, most recently Educational Excellence Everywhere (Department for Education (DfE), 2016) and before that The Importance of Teaching (DfE, 2010). Here, the DfE compared England with other EU countries, notably Finland and Germany:

- The most successful countries . . . are those where teaching has the highest status as a profession; South Korea recruits from their top 5 per cent of graduates and Finland from the top 10 per cent.

(DfE, 2010, p. 3) 
- Finland and South Korea - the highest performing countries in PISA

(DfE, 2010, p. 4)

- These regions and nations - from Alberta to Singapore, Finland to Hong Kong, Harlem to South Korea - have been our inspiration.

(DfE, 2010, p. 7)

Finland was not mentioned in the more recent white paper, but Germany was.

- Other education systems - from Shanghai and Singapore to Poland and Germany - are improving even faster than we are.

(DfE, 2016) (England declining)

The DfE's suggested path to improvement seems to advocate performing like Finland and Germany, but in those countries student teachers spend five years in universities on pre-service teacher education. Also, the workload of qualified teachers in school in England is much higher than in Finland, for instance, both in terms of student load and administration. Workload is a reason given for many leaving the profession in England.

$\begin{array}{lll}\text { Hours taught per week } & \begin{array}{l}\text { primary teacher } \\ \text { secondary teacher }\end{array} & \begin{array}{l}\text { Finland 18, England 27 } \\ \text { Finland 16, England 22 }\end{array} \\ \text { Number of pupils in a class } & \text { primary } & \text { Finland 20, England 30 } \\ & \text { Secondary } & \text { Finland 17, England 30 }\end{array}$

The DfE wants to achieve improvement by reducing the current time of around 30 days in many universities on School Direct courses to nothing in some instances (e.g. School-Centred Training Initiative Providers, known as SCITTs). In effect, trainees are paying $£ 9000$ in university fees to be low-cost labour in a school and potentially not qualified for the international market (including Ireland, Scotland and Wales, each of which is moving to closer alignment with other EU countries). Paradoxically, the DfE will allow newly privatised "academy" schools, now most of secondary schools, to employ teachers without Qualified Teacher Status. Let us draw out some more of the differences.

\section{School-based teacher education ${ }^{2}$}

University teacher education in England generally has been redefined through new priorities determined by, among other things, budgetary constraint, problems with teacher supply (Rowlands and Ruthven, 2011) and perceived school performance as compared with other countries (DfE, 2010). The teacher education function has been redistributed through governmental mandate to include professional and subject mentors within the school setting, challenging the more familiar university-based models. These mentors are themselves classroom teachers with their own classes to teach. This arrangement is thought to provide 


\section{Introduction}

immediate opportunity for student teachers to develop classroom skills (DfE, 2010). The student teachers spend much less time at university with tutors, where they have some limited scope to reflect on their practice and to consider educational theory. In many universities, the chief responsibility is oversight and accreditation for a process primarily administered by schools.

University teacher educators and school mentors, however, may have very different priorities for their roles in teacher training, such as those relating to how subject knowledge is understood, meeting the demands of testing, effectively using materials, learning a range of pedagogical strategies or building personal involvement in the subject. The very word "training" has been re-introduced in England rather than the term "education" preferable to many. Here the terms will often be used interchangeably, given the lack of consensus among those to whom we spoke. There are different ways of understanding the disciplinary knowledge that teachers need. Schools may prioritise the immediacy of classroom practice or following centralised guidance; universities may prioritise the more intellectually based elements, such as pedagogical subject knowledge (Shulman, 1986), building professional autonomy or meeting the demands of formal qualification (Hobson, Malderez and Tracey, 2009). Hitherto, relatively little research has been carried out on how increased school-based training supports the pedagogical subject knowledge aspects of teacher education, and how they are conceptualised, prioritised and enacted, so that further interventions can be better informed. I shall later discuss a few instances of subjects being reshaped to fit their new state of priority. A rare instance of how student teachers of science conceptualise their own teaching in schools is provided by Heywood and Parker (2010).

Meanwhile, the tendency in some countries of taking charge of school practices through a multitude of regulatory devices, such as through frequent testing, prescriptive curriculum and school inspection (Askew, Hodgen, Hossain and Bretscher, 2010; Brown, 2011), has resulted in subject knowledge becoming understood through a culture of performativity (e.g. Pampaka, Williams, Hutcheson, Wake, Black, Davis and Hernandez-Martinez, 2012). This insistence on following centralised documents has deflected attention from knowing how the redistribution of teacher education has resulted in student teachers actually understanding and meeting the professional challenges they face.

These changing policies affect the challenges faced by teacher educators and "school mentors", and in turn influence student teachers' conceptions of subject knowledge and its teaching. The policies also impact on the identity of the student teachers. Are they student teachers engaged in an educative process, developing the ability to lead curriculum initiatives as they later become professional teachers? Or are they trainees fulfilling the requirements of training, working to the current models of school practice as specified by the government? That is, are teachers curriculum makers, or curriculum implementers (Schwab, 1983; Clandinin and Connelly, 1992; Craig and Ross, 2008)? One is moved to suggest that school-based trainees are being prepared primarily for the latter and will take their chances in being carried along in the future rather than having been prepared 
directly to address changes in professional circumstances. We now turn to the contrasting situation in continental Europe. Here we shall find an approach that has provoked some concern through its lack of connection to school practice.

\section{University-based teacher education}

There are still many regional variations across Europe, yet: “Almost all countries introduced reforms in initial primary teacher education after the initiation of the Bologna Process (1999)" (ENTEP, Dimitropoulos), along with secondary subject teachers, and half of pre-primary sectors of education. The model is motivated by sharing good practices and creating mutual trust in the teaching qualifications awarded across member states with a view to enabling shared accreditation and greater mobility across European countries. The lengthy academic training often conducted by people with relatively little experience of schools can seem distant from the more practical challenges ahead. In Germany, teachers need to get through four to five years of university prior to being admitted to the school practicum phase of 18 months to two years. In Spain, all primary teachers study at university for four years, including short periods in school. Yet this investment retains wide support across European nations. As one German primary mathematics teacher educator put it: "The university is a space to question. What for? Why? How could it be different? Rather than being in a state of permanent emergency (as in school-based work) . . A teacher is not just a craftsman." This intensification of the academic component represents a further distancing from practical concerns for student teachers in those countries (Hudson and Zgaga, 2008). Once qualified, however, following an extended school placement after the academic component has been completed, rather more professional autonomy can be asserted than in the policy-dominated approach in England. That is, the teachers are given more responsibility for making local decisions and setting the curriculum.

\section{Contrasting the two models}

Lower-cost school-based teacher education may appeal to an increasing number of governments in building and influencing the practice of their teaching forces. But some questions immediately present themselves: Does it provide a viable alternative to university-based teacher education? Does it alter the composition of the pedagogical subject knowledge it seeks to support? Is it low-cost, or at least good value for money? Will England and its radical non-alignment with the international community become TIMSS/PISA superstars, or dunces? Perhaps England will be able to provide the answers to these questions for other countries in the foreseeable future. The impact of these contrasting approaches on different school subjects relates to the way in which conceptions of the subjects derive from where understandings of them are developed, whether in schools or in universities. For those in schools, little more may be done than enable teachers to work through commercial schemes as implementers of curriculum. 
For those following university-intensive courses, relatively low attention is given to the practical school aspects during the university element, where the creative aspect is not extensive. Pedagogical subject knowledge is a function of the educational domain in which it is encountered, and hence of the discourse that characterises that domain. That discursive structure can shape the actions of those subject to it. The student teachers' conceptions of teaching can be crafted around the apparatus of administrative control, which is restrictive, expressed in terms of curricula compliance or fitting in with existing school practices. This administrative restrictiveness in the name of policy implementation is potentially counter to pupils achieving both a positive disposition towards and functionality in the subjects in later study or professional life. Specifically, pedagogical subject knowledge derives from specific types of encounter in a model of teacher education. In the school-based models the teachers' conceptions of subject knowledge are developed without a great deal of explicit instruction from university specialists in the area. Rather, the teacher education function is achieved through the student teachers being immersed in the infrastructure of schooling. Student teachers are primarily guided by their school mentors through centralised curriculum documentation, or by textbooks chosen by head teachers. That is, the students' pedagogical knowledge is derived from their own practice referenced to existing or required conceptions of subject knowledge and patterned on the associated apparatus. Their way of talking about subject knowledge mirrors the official discourse. Consequentially, there is a strong reproductive dimension to the student teachers' understanding of school subjects. Subject knowledge is defined within very tight boundaries that give it little space to be something else, such as constructions generated by the teachers or pupils themselves. On the one hand, if subject knowledge is understood in terms of fixed results, levels and following procedures, then little opportunity is provided for the student teacher to develop an autonomous professional attitude to enquiry in the classroom. Rather, the students are subject to an externally imposed curriculum as represented by the schools to which they are assigned. They understand their own professionalism and identities in those terms. On the other hand, schoolbased models provide an avenue through which student teachers and their tutors can experience classroom teaching from new angles. In the school-based model described, student teachers retain some possibility of inspecting their practices in school from an external site so that their insider experience of meeting immediate demands can be reviewed against a more holistic understanding of what they are trying to achieve. University tutors, meanwhile, provided a responsive role in helping students to confront demanding classroom challenges in more creative ways, albeit in terms of administering subject knowledge to the prevailing models.

Ultimately, conceptions of educational improvement are very much a function of the country, or even local community, in which they apply and the state of affairs prevalent there. And it is this sense of contingency that underpins this book's focus on adjustments to new paradigms. It is unhelpful to suppose that we could identify trajectories of improvement that apply across all people and all 
phases of development. School subject knowledge has come to be a function of this newly described world, backed up by governments using these conceptions to set their policies. There is always a cost in the form of suppressions resulting from such generalist suppositions. To represent teaching practices as universal, spanning nations and generations, comes at a price in terms of teachers' ability to identify with the modes of education privileged in such comparisons. For England, decisions have been made as a result of which university infrastructures, and buildings, will no longer accommodate full-time students and new discourses of what is required to become a teacher have been established.

\section{Chapter outline}

Chapter 2 provides a detailed description of the empirical study documenting the arrival of the School Direct model of school-led teacher education. Chapter 3 develops the discussion of how research might be understood differently within school-based models. Chapter 4 provides fuller analysis of how subject knowledge changes within more compressed university courses. Chapter 5 takes the specific example of subject knowledge in mathematics teacher education and how school mathematics itself has evolved through successive policy changes. Chapters 6 and 7 consider what happens to theory within school-based models. Chapter 8 concludes the book.

In more detail:

Chapter 2 discusses the School Direct Research Project that concludes five years of empirical research into the effects of school-led training on the rationale and composition of university teacher education in England and considers the impacts of recent changes on the teaching profession. The project report, written by Tony Brown, Harriet Rowley and Kim Smith, was presented at a parliamentary seminar in the House of Lords in 2016. The report shows how the rejigging of training in the English model has been redistributed between university and school sites consequential to School Direct, altering how the content and composition of that training is decided. Teacher education has been split across the university and school sites, where trainees are "caught between two divorcing parents" (Bamber, 2015, p. 14). The flux is leading to uncertainty across role boundaries and, in turn, changes in practice. The impact on different school subjects resulting from these contrasting approaches relates to the way in which conceptions of the subjects derive from where understandings of them are developed, whether in schools or in universities. For those training in schools little more may be done than enable teachers to work through commercial schemes as implementers of curriculum. The report is discussed under six thematic headings: i) Local market conditions shape teacher education provision, ii) school-led training is altering the balance of power away from universities, iii) the composition of universities' contribution to teacher training is changing, iv) the composition of trainee pedagogical experience is being reconfigured, v) conceptions of pedagogical subject knowledge vary between schools and universities and vi) new research priorities are redefining teacher educator professionalism. 


\section{Introduction}

Chapter 3 shows more specifically how the expansion of school-based teacher training is impacting the practices of universities, schools and trainees. University tutors and managers were interviewed on how they experienced working in partnership with schools and how this impacted on the composition of their work. They reported on how their sense of professional purpose had been challenged through changing expectations. Their involvement in research is used as a barometer of these changes. Thus, the chapter follows the discussion of the sixth theme identified in the School Direct report, "new research priorities are redefining teacher educator professionalism". The teacher educators are depicted as wavering between governmental regulation and professional imperatives, where the latter comprise an uneasy alliance of expertise in school and academic rigour. Through depicting the unsettlement of practice and accounts of it, the chapter points to possible resolutions that might be achieved through more systematic resistance to external demands. That is, the university teacher educator identity results from the attempted resolution of these conflicting demands.

Chapter 4 depicts the situation in England, with respect to how adjustments to policy in teacher education have had implications for how subject knowledge is understood and for how job descriptions are defined. That is, the interface between teacher educator and subject knowledge representation has been changing. This chapter considers the experience of university teacher educators adjusting to new academic and operational conditions. On the one hand, the teacher educators are confronted with their subject specialism being set according to new learning objectives and to new time and curriculum constraints. On the other hand, their professional identity is reshaped in response to structural changes to teacher education where earlier job definitions had been reconfigured or removed. The chapter analyses resultant conceptions of subject knowledge and of teacher education emerging through this changing interface and how these conceptions are variously located across staffing arrangements. The chapter provides a theoretical account of how the teacher educator/trainee interface has been reshaped in line with the market-led terminology that governs current practices. Specifically, the analytical tools enable us to dismantle and restructure the prevalent symbolic order guiding current teacher practice and understanding, particularly our entrapment within specific discourses and identity constructs that shape our interactions with subject knowledge.

Chapter 5 takes school mathematics as a case study of a curriculum subject area. It is shown to be a function of its discursive environment where the language being used formats mathematical activity. The chapter explores this theme through an extended discussion of how the conduct of mathematical teaching and learning is restricted by regulative educational policies. It considers how mathematics is discursively produced by student teachers within an employmentbased model of teacher education in England, where there is a low university input. It is argued that teacher reflections on mathematical learning and teaching within the course are patterned discursively in line with formal curriculum framings, assessment requirements and the local demands of their placement school. Both teachers and students are subject to regulative discourses that shape their 
actions and, consequentially, this regulation influences the forms of mathematical activity that can take place. It is shown how university sessions can provide a critical platform from which to interrogate these restrictions and renegotiate them.

Chapter 6 provides a more detailed account of the opportunities opened by new approaches to teacher education. It considers how conceptions of theory within initial teacher education in England might adjust to new conditions where most learning how to teach is school-based. Mature student teachers on a programme situated primarily in an employing school were monitored within a practitioner enquiry by their university programme tutors according to how they progressively understood theory. The tutors, meanwhile, also focused on how their own conceptions of theory responded and evolved in relation to their students' changing perceptions. This shift of perspective resulted in the students retrospectively identifying and developing theoretical and analytical capabilities. University sessions again became a reflective platform from which to critically interrogate the emergent story of what it is to be a teacher in a school. There are implications for schools and universities about what it is to learn to be a teacher.

Chapter 7 documents collaborative action research by teacher educators involved in the work described in the last chapter, focusing on the changing demands of their development work with the trainees. The resultant struggle of professional identity for tutors is productive, adjusting educative processes to new circumstances. The actor of action research so equipped mobilises a conception of theory supportive of more responsive subjective modes within wider professional functionality. Methodologically, the actor is depicted as identifying with on-going cultural adjustments through reflective data.

Chapter 8 completes the book. It summarises how recent policy changes have reconfigured both the professional spaces and the people working within them. It gathers together some of the theoretical apparatus that has been used in this book to make sense of the changes, and sketches possible trajectories for further work. It surveys how the changes relate to other international movements. The book concludes by proposing a distinctive role for university teacher education.

\section{Notes}

1 This chapter draws on Brown, T., Rowley, H. and Smith, K. (2015a). The beginnings of school-led teacher training: New challenges for university teacher education. School Direct Research Project. Final Report. Manchester Metropolitan University, Manchester.

2 The next three subsections draw on material from: Brown, T. (2017). The political shaping of teacher education in STEM areas. In J. Clandinin and J. Husu (Eds.). Sage international handbook of teacher education. New York: Sage. 


\section{References}

Adams, J. (2010). Risky choices: The dilemmas of introducing contemporary art practices into schools. British Journal of Sociology of Education, 31(6), 683-701.

Adams, J. (2013). The Artful Dodger: Creative resistance to neo-liberalism in education. Review of Education, Pedagogy and Cultural Studies, 35 (4), 242-255.

Alexander, R. (Ed.). (2009). Children, their world, their education: Final report and recommendations of the Cambridge Primary Review. London: Routledge.

Althusser, L. (1971). Lenin and philosophy and other essays. Translated and edited by B.

Brewster . London: New Left Books.

Anderson, R. (2002). Reforming science teaching: What research says about inquiry. Journal of Science Teacher Education, 13 (1), 1-12.

Askew, M. , Hodgen, J. , Hossain, S. and Bretscher, N. (2010). Values and variables: A review of mathematics education in high-performing countries. London: The Nuffield Foundation. Atkinson, D. (2004). Theorising how student teachers form their identities in initial teacher education. British Education Research Journal, 30(3), 379-394.

Atkinson, D. (2011). Art, equality and learning: Pedagogies against the state. Rotterdam: Sense Publishers.

Attard, K. (2012). The role of narrative writing in improving professional practice. Educational Action Research, 20(1), 161-175.

Badiou, A. (2009). Logics of worlds. London: Continuum.

Badiou, A. (2011). Second manifesto for philosophy. London: Polity.

Ball, S. (2001). Teachers' soul and the terrors of performativity. Unpublished manuscript, University of London at London, England.

Ball, S. (2004). Education for sale! The commodification of everything. Kings Annual Education Lecture, University of London.

Bamber, S. (2015). Learning to teach mathematics: Navigating the landscape of teacher education. Doctoral dissertation, University of Chester, UK.

Bamfeld, L. (Ed.). (2014). The role of research in teacher education: Reviewing the evidence: Interim report of the BERA-RSA inquiry. London: British Educational Research Association. Barad, K. (2007). Meeting the universe halfway: Quantum physics and the entanglement of matter and meaning. Durham, NC: Duke University Press.

Barton, B. (2007). The language of mathematics: Telling mathematical tales. New York:

Springer.

Beauchamp, G. , Clarke, L. , Hulme, M. , Jephcote, M. , Kennedy, A. , Magennis, G. , Menter, I. , Murray, J. , Mutton, T. , O'Doherty, T. and Peiser, G. (2016). Teacher education in times of change. Bristol: Policy Press.

Beauchamp, G. , Clarke, L. , Hulme, M. and Murray, J. (2015). Teacher education in the United Kingdom post devolution: Convergences and divergences. Oxford Review of Education, 41 (2), 154-170.

Bibby, T. (2009). How do pedagogic practices impact on learner identities in mathematics? A psychoanalytically framed response. In L. Black, H. Mendick and Y. Solomon (Eds.), Mathematical relationships: Identities and participation. London: Routledge (pp. 123-135). Bibby, T. (2010). Classrooms and their discontents: Education and psychoanalysis. London: Routledge.

Black, L. , Mendick, H. and Solomon, Y. (2009). Mathematical relationships: Identities and participation. New York: Routledge.

Blanton, M. , Westbrook, S. and Carter, G. (2005). Using Valsiner's zone theory to interpret teaching practices in mathematics and science classrooms. Journal of Mathematics Teacher Education, 8 (1), 5-33.

Bostock, J. (2012). Conceptualizing teacher education in professional training. Doctor of Education thesis, Manchester Metropolitan University.

Boyd, P. and Harris, K. (2010). Becoming a university lecturer in teacher education: Expert school teachers reconstructing their pedagogy and identity. Professional Development in Education, 36 (1-2), 9-24.

Boylan, M. , Wolstenholme, C. , Maxwell, B. , Jay, T. , Stevens, A. and Demack, S. (2016). Longitudinal evaluation of the mathematics teacher exchange: China-England. Interim research report. London: Department for Education. 
Bracher, M. (1994). On the psychological and social functions of language: Lacan's theory of the four discourses. In M. Bracher (Ed.), Lacanian theory of discourse: Subject, structure and society. New York: New York University Press (pp. 107-128).

Britzman, D. P. (2009). The very thought of education: Psychoanalysis and the impossible professions. Albany: State University of New York Press.

Brown, L. and Coles, A. (2012). Developing 'deliberate analysis' for learning mathematics and for mathematics teacher education: How the enactive approach to cognition frames reflection. Educational Studies in Mathematics, 80 (1-2), 217-231.

Brown, M. (2011). Going back or going forward? Tensions in the formulation of a new national curriculum in mathematics. Curriculum Journal, 22 (2), 151-165.

Brown, M. , Askew, M. , Millett, A. and Rhodes, V. (2003). The key role of educational research in the development and evaluation of the National Numeracy Strategy. British Educational Research Journal, 29 (5), 655-667.

Brown, M. , Millett, A. , Bibby, T. and Johnson, J. (2000). Turning our attention from the what to the how: The National Numeracy Strategy. British Educational Research Journal, 26 (4), 457-472.

Brown, T. (1996). Creating data in practitioner research. Teaching and Teacher Education, 12 (3), 261-270.

Brown, T. (2001). Mathematics education and language. Dordrecht: Springer.

Brown, T. (2008). Desire and drive in researcher subjectivity: The broken mirror of Lacan. Qualitative Inquiry, 14 (4), 402-423.

Brown, T. (2011). Mathematics education and subjectivity: Cultures and cultural renewal. Dordrecht: Springer.

Brown, T. (2016). Rationality and belief in learning mathematics. Educational Studies in Mathematics, 92 (1), 75-90.

Brown, T. , Atkinson, D. and England, J. (2006). Regulative discourses in education: A Lacanian perspective. Bern, Switzerland: Peter Lang Publishers.

Brown, T. and Clarke, D. (2013). Institutional contexts for research in mathematics education. In M. Clements , A. Bishop , C. Keitel , J. Kilpatrick and F. Leung (Eds.), Third international handbook of mathematics education. Dordrecht: Springer.

Brown, T. , Devine, N. , Leslie, E. , Paiti, M. , Sila'ila'i, E. , Umaki, S. and Williams, J. (2006). Reflective engagement in cultural history: A Lacanian perspective on Pasifika teachers in New Zealand. Pedagogy, Culture and Society, 15 (1), 107-118.

Brown, T. and Fisher, T. (2016). A white paper demanding scrutiny. Research intelligence, Summer.

Brown, T. , Hodson, E. and Smith, K. (2013). TIMSS maths has changed real maths forever. For the Learning of Mathematics, 33 (2), 38-43.

Brown, T. and Jones, L. (2001). Action research and postmodernism: Congruence and critique. Buckingham: Open University Press.

Brown, T. and McNamara, O. (2005). New teacher identity and regulative government: The discursive formation of primary mathematics teacher education. Dordrecht: Springer.

Brown, T. and McNamara, O. (2011). Becoming a mathematics teacher: Identity and identifications. Dordrecht: Springer.

Brown, T. and Roberts, L. (2000). Memories are made of this: Temporality and practitioner research'. British Educational Research Journal, 26 (5), 649-659.

Brown, T. , Rowley, H. and Smith, K. (2014). Rethinking research in teacher education. British Journal of Education Studies, 62 (3), 281-296.

Brown, T. , Rowley, H. and Smith, K. (2015a). The beginnings of school-led teacher training: New challenges for university teacher education. School Direct Research Project. Final Report. Manchester Metropolitan University, Manchester.

Brown, T. , Rowley, H. and Smith, K. (2015b). Sliding subject positions: Knowledge and teacher educators. British Educational Research Journal, 42 (3), 492-507.

Browne, L. and Reid, J. (2012). Changing localities for teacher training: The potential impact on professional formation and the university sector response. Journal of Education for Teaching: International Research and Pedagogy, 38 (4), 497-508.

Burns, C. and Myhill, D. (2004). Interactive or inactive? A consideration of the nature of interaction in whole class teaching. Cambridge Journal of Education, 34 (1), 35-49. 
Butler, J. (1993). Bodies that matter. New York and London: Routledge.

Butler, J. (1997). The psychic life of power. Stanford: Stanford University Press.

Butler, J. (2005). Giving and account of oneself. New York: Fordham University Press.

Calder, N. (2012). The layering of mathematical interpretations through digital media.

Educational Studies in Mathematics, 80 (1-2), 269-285.

Calder, N. and Brown, T. (2010). Learning through digital technologies. In M. Walshaw (Ed.),

Unpacking pedagogy: New perspectives for mathematics classrooms. Charlotte, NC:

Information Age Publishing.

Carter, A. (2015). Carter review of initial teacher training.

www.gov.uk/government/uploads/system/uploads/attachment_data/file/399957/Carter_Review. pdf

Chap Sam, L. (2002). Public images of mathematics. Philosophy of Mathematics Education Journal, 15.

Childs, A. , Edwards, A. and McNicholl, J. (2013). Developing a multi-layered system of distributed expertise: What does cultural historical theory bring to understanding workplace learning in school-university partnerships? In O. McNamara, J. Murray and M. Jones (Eds.), Workplace learning in teacher education. London: Springer.

Christie, D. , Donoghue, M. , Kirk, G. , McNamara, M. , Menter, I. , Moss, G. , Noble-Rogers, J. , Oancea, A. , Rogers, C. , Thomson, P. and Whitty, G. (2012). Prospects for education research in education departments in Higher Education Institutions in the UK. London: BERA-UCET

Working Group on Education Research. www.bera.ac.uk/news/beraucet-report

Clandinin, D.J. and Connelly, F. M. (1992). Teacher as curriculum maker. In P. W. Jackson

(Ed.), Handbook of research on curriculum. New York: Macmillan (pp. 363-401).

Clandinin, D.J. , Long, J. S. , Schaefer, L. , Downey, C.A. , Steeves, P. , Pinnegar, E. ,

McKenzie Robblee, S. and Wnuk, S. (2015). Early career teacher attrition: Intentions of

teachers beginning. Teaching Education, 26 (1), 1-16.

Clarke, M. and Phelan, A. (2017). Teacher education and the political. London: Routledge.

Cochran-Smith, M. (2016). Foreword. In G. Beauchamp , L. Clarke, M. Hulme, M. Jephcote ,

A. Kennedy , G. Magennis , I. Menter , J. Murray , T. Mutton , T. O'Doherty and G. Peiser

(Eds.), Teacher education in times of change. Bristol: Policy Press (pp. x-xvi).

Cohen, D. (1990). A revolution in one classroom: The case of Mrs. Oublier. Educational

Evaluation and Policy Analysis, 12, 327-345.

Cole, M. (1996). Cultural Psychology; A once and future discipline. Cambridge, Mass: Belknap Press.

Convery, A. (1999). Listening to teacher' stories: Are we sitting too comfortably? International Journal of Qualitative Studies in Education, 12 (2), 131-146.

Cooper, B. and Dunne, M. (1999). Assessing children's mathematical ability. Buck-ingham: Open University Press.

Craig, C. J. and Ross, V. (2008). Cultivating the image of teachers and curriculum makers. In F. M. Connelly (Ed.), The Sage handbook of curriculum and instruction. Los Angeles: SAGE Publications Inc. (pp. 282-305).

Critchley, S. (2008). Infinitely demanding: Ethics of commitment, politics of resistance. London: Verso.

Darling-Hammond, L. (2017). Empowered educators: How high performing systems shape teaching quality around the world. San Francisco: Jossey-Bass.

Darling-Hammond, L. and Lieberman, A. (Eds.). (2012). Teacher education around the world:

Teacher quality and school development. London: Routledge.

Davies, B. (2006). Subjectification: The relevance of Butler's analysis for education. British Journal of Sociology of Education, 27 (4), 425-438.

Delamont, S. (Ed.). (2010). Anthropological perspectives on learning and teaching: Legitimate peripheral participation revisited. Teaching and Teacher Education, 26 (1), 1-144.

Department for Education . (2010). The importance of teaching: The schools white paper.

London: The Stationary Office.

Department for Education . (2011). Training our next generation of outstanding teachers.

London: The Stationary Office.

Department for Education . (2013). School workforce in England.

www.gov.uk/government/uploads/system/uploads/attachment_data/file/193090/SFR_15_2013.p

df 
Department for Education . (2016). Educational excellence everywhere. London: DfE. Dowling, P. (1998). The sociology of mathematics education: Mathematical myths/pedagogic texts. London: Falmer Press.

Doxiadis, A. and Mazur, B. (Eds.). (2012). Circles disturbed: The interplay of mathematics and narrative. Princeton: Princeton University Press.

Dunne, M. , Lock, R. and Soares, A. (1996). Partnership in initial teacher training: After the shotgun wedding. Educational Review, 48 (1), 41-53.

Ellis, V. , Glackin, M. , Heighes, D. , Norman, M. , Norris, K. , Spencer, I. and McNicholl, J. (2013). A difficult realisation: The proletarianisation of higher education-based teacher educators. Journal of Education for Teaching: International Research and Pedagogy, 39 (3), 266-280.

Ellis, V. and McNicholl, J. (2015). Transforming teacher education. London: Bloomsbury. Ellis, V. , McNicholl, J. and Pendry, A. (2012). Institutional conceptualisations of teacher education as academic work in England. Teaching and Teacher Education, 28 (5), 685-693. Enosh, G. , Ben-Ari, A. and Buchbinder, E. (2008). Sense of differentness in the construction of knowledge. Qualitative Inquiry, 14 (3), 450-465.

ENTEP: Dimitropoulos, A. (accessed 2016). The Bologna process and teacher education structures in Europe: Creating a European teacher education area. European Network on Teacher Education Policies.

Fennema, E. and Nelson, B. (Eds.) (1997). Mathematics teachers in transition. New Jersey: Lawrence Erlbaum Associates Inc.

Fink, B. (1995). The Lacanian subject. Princeton, NJ: Princeton University Press.

Freeman, B. , Marginson, S. and Tytler, R. (Eds.). (2015). The age of STEM: Policy and practice in science, technology, engineering and mathematics across the world. Oxon, UK: Routledge.

Fullan, M. (2001). The new meaning of educational change. New York: Teachers College Press.

Furlong, J. , Barton, L. , Miles, S. , Whiting, C. and Whitty, G. (2000). Teacher education in transition. Buckingham: Open University Press.

Furlong, J. and Lawn, M. (Eds.). (2011). Disciplines of education: Their role in the future of education research. London: Routledge.

Galton, M. (2002). A national curriculum balance sheet. Education Review, 15 (2), 15-21.

Garcia, R. , Saiz, M. , and Rivera, A. (2011). Cognitive cultural analysis of low achievement in TIMSS: Evaluating wrong answers in 8th grade. In B. Ubuz (Ed.).

Gebremichael, A. (2011). Perceptions of relevance of prior experiences of mathematics in an Ethiopian preparatory school. In B. Ubuz (Ed.).

Goldacre, B. (2013). Building evidence into education.

http://media.education.gov.uk/assets/files/pdf/b/ben\%20goldacre\%20paper.pdf

Goode, J. and Margolis, J. (2011). Exploring computer science: A case study of school reform. ACM Transactions on Computing Education, 11 (2), Article 12, 1-16

Goos, M. (2005). A sociocultural analysis of the development of pre-service and beginning teachers' pedagogical identities as users of technology. Journal of Mathematics Teacher Education, 8 (1), 35-59.

Griffin, R. (2012). Teacher education in Sub-Saharan Africa: Closer perspectives. Didcot, UK: Symposium Books Ltd.

Hammon, M. (2011). Beliefs and ICT: What can we learn from experienced educators? Technology, Pedagogy and Education, 20 (3), 289-300.

Handal, B. and Herrington, A. (2003). Mathematics teachers' beliefs and curriculum reform. Mathematics Education Research Journal, 15 (1), 59-69.

Hanley, C. (2017). An exploration of educative praxis: Reflections on Marx's concept of praxis, informed by the Lacanian concepts act and event. Educational Philosophy and Theory, 49 (10), 1006-1015. doi:10.1080/00131857.2016.1273087

Hanley, C. and Brown, T. (2016). Developing a university contribution to teacher education: Creating an analytical space for learning narratives. Journal of Curriculum Studies, 49 (3), 352-368. doi:10.1080/00220272.2016.1140811

Hanley, C. and Brown, T. (2017). Thinking with certainty or with doubt: A Lacanian theorisation of discursive knowledge in teacher education. Discourse: Studies in the Cultural Politics of Education, 1-13. doi:10.1080/01596306.2017.1316238 
Hanley, U. (2007). Fantasies of teaching: Handling the paradoxes inherent in models of practice. British Educational Research Journal, 33 (2), 253-271.

Hanley, U. (2010). Teachers and curriculum change: Working to get it right. In M. Walshaw (Ed.), Unpacking pedagogy: New perspectives for the mathematics classroom. Charlotte, NC: New Age Publishing.

Harrison, J. and McKeon, F. (2010). Perceptions of beginning teacher educators of their development in research and scholarship: Identifying the 'turning point' experiences. Journal of Education for Teaching: International Research and Pedagogy, 36 (1), 19-34.

Heron, J. (1996). Co-operative inquiry. London: Sage.

Heywood, D. and Parker, J. (2010). The pedagogy of physical science. Dordrecht: Springer. Hobson, A. J. (2003). Trainee teachers' conceptions and evaluations of 'theory' in initial teacher training. Mentoring and Tutoring, 11 (3), 245-261.

Hobson, A. J. , Malderez, A. and Tracey, L. (2009). Navigating initial teacher training: Becoming a teacher. London: Routledge.

Hodson, E. , Smith, K. and Brown, T. (2012). Reasserting theory in professionally-based initial teacher education. Teachers and Teaching, 18 (2), 181-195.

Holligan, C. (1997). Theory in initial teacher education: Trainees' perceptions on its utility - A case study. British Educational Research Journal, 23 (4), 533-551.

Holmes, R. (2010). Cinemaethnographic specta(c)torship: Discursive readings of what we choose to (dis)possess. Cultural Studies $\leftrightarrow$ Critical Methodologies, 10, 221-223.

Hordern, J. (2014). The logic and implications of school-based teacher formation. British Journal of Educational Studies, 62(3), 231-248.

Hudson, B. (2017). Overcoming fragmentation in teacher education policy and practice.

Cambridge: Cambridge University Press.

Hudson, B. and Zgaga, P. (Eds.). (2008). Teacher education policy in Europe: A voice of higher education institutions. Umeå: Monographs on Journal of Research in Teacher Education, Faculty of Teacher Education, University of Umeå.

Jones, M. and Straker, K. (2006). What informs mentors' practice when working with students and new teachers? An investigation in mentors' professional knowledge base. Journal of Education for Teaching, 32 (2), 165-184.

Jove, G. (2011). How do I improve what I am doing as a teacher, teacher educator and actionresearcher through reflection? A learning walk from Lleida to Winchester and back again.

Educational Action Research, 19 (3), 261-278.

Kemmis, S. (2010). What is to be done? The place of action research. Educational Action Research, 18 (4), 417-427.

Klein, M. (2012). How inconvenient assumptions affect preservice teachers' uptake of new interactional patterns in mathematics: Analysis and aspiration through a bifocal lens.

Educational Studies in Mathematics, 80 (1-2), 25-40.

Korthagen, F. (2010). Situated learning theory and the pedagogy of teacher education: Towards an integrative view of teacher behavior and teacher learning. Teaching and Teacher Education, 26, 98-106.

Krogh, L. B. and Thomsen, P. V. (2005). Studying students' attitudes towards science from a cultural perspective but with a quantitative methodology: Border crossing into the physics classroom. International Journal of Science Education, 27, 281-302.

Krzywacki, H. , Koistinen, L. and Lavonen, J. (2011). Assessment in Finnish mathematics education: Various ways, various needs. In B. Ubuz (Ed.), Proceedings of the 35th annual conference of the international group on the psychology of mathematics education. Ankara, Turkey: Orta Dogu Teknik Üniversitesi [Middle East Technical University] (Vol. 1, pp. 340). Kynigos, C. and Argyris, M. (2004). Teacher beliefs and practices formed during an innovation with computer-based exploratory mathematics in the classroom. Teachers and Teaching: Theory and Practice, 10 (3), 247-273.

Labaree, D. (1995). The lowly status of teacher education in the United States. In N. K. Shimahara and I. Z. Holowinsky (Eds.), Teacher education in industrialized nations. New York: Garland Publishing.

Lacan, J. (1977). The four fundamental concepts of psychoanalysis. London: Karnac.

Lacan, J. (2006). Ecrits. New York: Norton.

Lacan, J. (2007). The other side of psychoanalysis: The seminar of Jacques Lacan: Book XVII. London: Norton. 
Lacan, J. (2008). My teaching. London: Verso.

Lasky, S. (2005). A sociocultural approach to understanding teacher identity, agency and professional vulnerability in a context of secondary school reform. Teaching and Teacher Education, 21 (8), 899-916.

Lather, P. (2007). Getting lost: Feminist efforts toward a double(d) science. Albany: State University of New York Press.

Lave, J. and Wenger, E. (1991). Situated learning: Legitimate peripheral participation.

Cambridge: Cambridge University Press.

Lerman, S. (2000). A case of interpretations of 'social': A response to Steffe \& Thompson. Journal for Research in Mathematics Education, 31 (2), 210-227.

Lewis, T. and Cho, D. (2005). Education and event: Thinking radical pedagogy in the era of standardization. SIMILE Studies in Media \& Information Literacy Education, 5 (2), 1-11.

Lloyd, G. M. (1999). Two teachers' conceptions of a reform-oriented curriculum: Implications for mathematics teacher development. Journal of Mathematics Teacher Education, 2 (3), 227-252.

Marshall, T. (2014). New teachers need access to powerful educational knowledge. British Journal of Educational Studies, 62 (3), 265-279.

Martindale, J. (2014). What impact is the school direct model having on the mentoring and teacher educator relationships in secondary initial teacher training? MA Education dissertation, Manchester Metropolitan University.

McKeon, F. and Harrison, J. (2010). Developing pedagogical practice and professional identities of beginning teacher educators. Professional Development in Education, 36 (1-2), 25-44.

McMahon, T. (2010). Peer feedback in an undergraduate programme: Using action research to overcome trainees' reluctance to criticize. Educational Action Research, 18 (2), 273-287.

McNamara, O. and Murray, J. (2013). The school direct programme and its implications for research informed teacher education and teacher educators. York: Higher Education Academy.

Menter, I. , Brisard, E. and Smith, I. (2006). Convergence or divergence? Initial teacher education in Scotland and England. Edinburgh: Dunedin Academic Press.

Mishra, L. (2017). Teacher education in India. Cambridge: Cambridge Scholars Publishing. Morgan, C. (1998). Writing mathematically. London: Falmer.

Morris, E. (2013). Michael Gove has washed his hands of planning for the future. The Guardian. http://www.theguardian.com/education/2013/sep/23/shortage-of-teachers

Murray, J. (2014). Teacher educators' constructions of professionalism: A case study, AsiaPacific. Journal of Teacher Education, 42 (1), 7-21.

National Audit Office . (2016). Training new teachers. London: Department for Education. National College of Teaching and Leadership . (2016). The customer journey to initial teacher training (ITT). National College of Teaching and Leadership.

National Council for Excellence in the Teaching of Mathematics . (2014). Mastery approaches to mathematics and the new national curriculum. National Council for Excellence in the Teaching of Mathematics.

Ng, S. , Lopez-Real, F. and Rao, N. (2003). Early mathematics teaching: The relationship between teachers' beliefs and classroom practices. In B. J. Dougherty and J. T. Zilliox (Eds.), Proceedings of the 2003 joint meeting of PME and PMENA, Volume 3. Honolulu: University of Hawaii.

Niesz, T. (2010). Chasms and bridges: Generativity in the space between educators' communities of practice. Teaching and Teacher Education, 26 (1), 37-44.

Nolan, K. (2012). Dispositions in the field: Viewing mathematics teacher education through the lens of Bourdieu's social field theory. Educational Studies in Mathematics, 80 (1-2), 201-215. Pampaka, M. , Williams, J. , Hutcheson, G. , Wake, G. , Black, L. , Davis, P. and HernandezMartinez, P. (2012). The association between mathematics pedagogy and learners' dispositions for university study. British Educational Research Journal, 38 (3), 473-496.

Passy, R. (2012). Surviving and flourishing in a neoliberal world: Primary trainees talking. British Educational Research Journal, 39 (6), 1060-1075.

Pimm, D. (1987). Speaking mathematically. London: Routledge.

Pirrie, A. and MacLeod, G. (2010). Tripping, slipping and losing the way: Moving beyond methodological difficulties in social research. British Educational Research Journal, 36 (3), 367-378.

Poultney, V. (2017). Evidence-based teaching in primary education. St Albans: Critical Publishing. 
Price, A. and Willett, J. (2006). Primary teachers' perceptions of the impact of initial teacher training on primary schools. Journal of In-Service Education, 32 (1), 33-45.

Quicke, T. (2010). Narrative strategies in educational research: Reflections on a critical autoethnography. Educational Action Research, 18 (2), 239-254.

Reid, J. , Brown, T. and Smith, K. (2012). Theories and practices for teacher education. Australasian association of research in education, Sydney.

Remillard, J. T. (2000). Can curriculum materials support teachers' learning? Elementary School Journal, 11 (4), 331-350.

Remillard, J. T. (2005). Examining key concepts in research on teachers' use of mathematics curricula. Review of Educational Research, 75 (2), 211-246.

Remillard, J. T. and Bryans, M. (2004). Teachers' orientations towards mathematics curriculum materials: Implications for teacher learning. Journal for Research in Mathematics Education, 35 (5), 352-388.

Remillard, J. T. and Geist, P. K. (2002). Supporting teachers' professional learning by navigating openings in the curriculum. Journal of Mathematics Teacher Education, 5 (1), 7-34. Reynolds, R. , Ferguson-Patrick, K. and McCormack, A. (2013). Dancing in the ditches: Reflecting on the capacity of a university/school partnership to clarify the role of a teacher educator. European Journal of Teacher Education, 36 (3), 1-13.

Rivera Maulucci, M. (2010). Becoming an urban science teacher: Teacher learning as a collective performance of conceptions. In W.-M. Roth (Ed.), Re/structuring science education. Dordrecht: Springer.

Romberg, T. (1997). Mathematics in context: Impact on teachers. In E. Fennema and B. Scott Nelson (Eds.), Mathematics teachers in transition. Mahwah, NJ: Lawrence Erlbaum Associates Inc.

Rowland, T. and Ruthven, K. (Eds.). (2011). Mathematical knowledge in teaching. Dordrecht: Springer.

Rowland, T. , Turner, F. , Thwaites, A. and Huckstep, P. (2009). Developing primary mathematics teaching: Reflecting on practice with the knowledge quartet. London: Sage.

Sahin, C. , Bullock, K. and Stables, A. (2002). Teachers' beliefs and practices in relation to their beliefs about questioning at Key Stage 2. Educational Studies, 28 (4), 371-384.

Schwab, J. (1983). The practical 4: Something for curriculum professors to do. Curriculum Inquiry, 13 (3), 239-265.

Senger, E. (1999). Reflective reform in mathematics: The recursive nature of teacher change. Educational Studies in Mathematics, 37 (3), 199-221.

Shagrir, L. (2010). Professional development of novice teacher educators: Professional self, interpersonal relations and teaching skills. Professional Development in Education, 36 (1-2), 45-60.

Shulman, L. (1986). Those who understand: Knowledge growth in teaching. Educational Researcher, 15 (2), 4-14.

Simon, M. and Tzur, R. (1999). Explicating the teacher's perspective from the researchers' perspectives: Generating accounts of mathematics teachers' practice. Journal for Research in Mathematics Education, 30 (3), 252-264.

Skott, J. (2001). The emerging practices of a novice teacher: The roles of his school mathematics images. Journal of Mathematics Teacher Education, 4, 3-28.

Smith, K. and Hodson, E. (2010). Theorising practice in initial teacher training. Journal of Education for Teaching, 36 (3), 259-275.

Smith, K. , Hodson, E. and Brown, T. (2013a). Teaching educator changing perceptions of theory. Educational Action Research Journal, 21 (2), 237-252.

Smith, K. , Hodson, E. and Brown, T. (2013b). The discursive production of classroom mathematics. Mathematics Education Research Journal, 25, 379-397.

Solomon, Y. (1998). Teaching mathematics: Ritual, principle and practice. Journal of Philosophy of Education, 32 (3), 377-390.

Solomon, Y. (2008). Mathematical literacy: Developing identities of inclusion. London: Routledge.

Somekh, B. and Zeichner, K. (2009). Action research for educational reform: Remodelling action research theories \& practices in local contexts. Educational Action Research, 17 (1), $5-21$. 
Sorenson, P. (2014). Collaboration, dialogue and expansive learning: The use of paired and multiple placements in the school practicum. Teaching and Teacher Education, 44, 128-137. Sorensen, P. , Newton, L. and McCarthy, S. (2012). Developing a science teacher education course that supports student teachers' thinking and teaching about the nature of science.

Research in Science \& Technological Education, 30 (1), 29-47.

Steffe, L. and Kieran, T. (1994). Radical constructivism and mathematics education. Journal for Research in Mathematics Education, 25 (6), 711-733.

Sztajn, P. (2003). Adapting reform ideas in different mathematics classrooms: Beliefs beyond mathematics. Journal of Mathematics Teacher Education, 6 (1), 53-75.

Tack, H. and Vanderlinde, R. (2014). Teacher educators' professional development: Towards a typology of teacher educators' researchly dispositions. British Journal of Educational Studies, 62 (3), 297-315.

Taylor, W. (1983). Teacher education: Achievements, shortcomings and perspectives. Paper presented at The John Adams Memorial Lecture. The Institute of Education, London.

Teacher Development Agency . (2009). Guidance to accompany the professional standards for qualified teacher status and requirements for initial teacher training. London: Department for Education.

Teaching Agency . (2012). Initial teacher training (ITT) criteria. London: Teaching Agency. Timmons Flores, M. (2007). Navigating contradictory communities of practice in learning to teach for social justice. Anthropology \& Education Quarterly, 38 (4), 380-404.

Torrance, H. and Pryor, J. (2001). Developing formative assessment in the classroom: Using action research to explore and modify theory. British Educational Research Journal, 27 (5), 615-631.

Tytler, R. , Swanson, D. and Appelbaum, P. (2015). Subject matters of science, technology, engineering, and mathematics. In M. He, B. Schultz and W. Schubert (Eds.), The SAGE guide to curriculum in education. London: Sage.

Tzur, R. , Simon, M. , Heinz, K. and Kinzel, M. (2001). An account of a teacher's perspective on learning and teaching mathematics: Implications for teacher development. Journal of Mathematics Teacher Education, 4 (3), 227-254.

Ubuz, B. (Ed.). (2011). Proceedings of the 35th Annual Conference of the International Group on the Psychology of Mathematics Education, Volume 1. Ankara, Turkey: Orta Dogu Teknik Üniversitesi [Middle East Technical University] (p. 340).

UCET . (2011). National College designates 100 teaching schools in England. www.ucet.ac.uk/search?q=Press+releases

Van Velzen, C. , van der Klink, M. , Swennen, A. and Yaffe, E. (2010). The induction and needs of beginning teacher educators. Professional Development in Education, 36 (1-2), 61-75.

Van Zoest, L. R. and Bohl, J. V. (2002). The role of reform curricular materials in an internship: The case of Alice and Gregory. Journal of Mathematics Teacher Education, 5, 265-288.

Wagner, D. (2012). Opening mathematics texts: Resisting the seduction. Educational Studies in Mathematics, 80 (1-2), 153-170.

Wall, T. (2013). Professional identity and agency in the university accreditation of commercial training. Doctor of Education thesis, Manchester Metropolitan University.

Walls, F. (2009). Mathematical subjects: Children talk about their mathematical lives. New York: Springer.

Walshaw, M. (2007). Working with Foucault in education. Rotterdam: Sense Publishers.

Walshaw, M. (2008). Developing theory to explain learning to teach. In T. Brown (Ed.), The psychology of mathematics education: A psychoanalytic displacement. Rotterdam: Sense Publishers (pp. 119-138).

Walshaw, M. (2010). Learning to teach: Powerful practices at work during the praticum. In M.

Walshaw (Ed.), Unpacking pedagogy: New perspectives for mathematics classrooms.

Charlotte, NC: Information Age Publishing (pp. 109-128).

Walshaw, M. and Brown, T. (2012). Affective productions of mathematical experience.

Educational Studies in Mathematics, 80 (1-2), 185-199.

Walton, J. (2011). A living theory approach to teaching in higher education. Educational Action Research, 19 (4), 567-578.

Watson, A. and Winbourne, P. (Eds.). (2008). New directions for situated cognition in mathematics. Dordrecht: Springer. 
Wells, D. (2012). Computing in schools: Time to move beyond ICT? Research in Secondary Teacher Education, 2 (1), 8-13.

Wenger, E. (2000). Communities of practice: Learning, meaning and identity. Cambridge: Cambridge University Press.

Wenger, E. (2013). Communities of practice: Learning, meaning and identity. Cambridge: Cambridge University Press.

White, E. (2012). Exploring the professional development needs of new teacher educators situated solely in school: Pedagogical knowledge and professional identity. Professional Development in Education, 39 (1), 82-98.

White, E. (2014). Being a teacher and a teacher educator - Developing a new identity? Professional Development in Education, 40 (3), 436-449.

Williams, J. and Ritter, J. (2010). Constructing new professional identities through self-study: From teacher to teacher educator. Professional Development in Education, 36 (1-2), 77-92. Williams, P. (2008). Independent review of mathematics teaching in early years settings and primary schools. London: Department for Children, Schools and Families.

Wilson, E. (2012). Building social capital in teacher education through university - School partnership. In M. Evans (Ed.), Teacher education and pedagogy: Theory, policy and practice. Cambridge: Cambridge University Press.

Wilson, M. and Goldenberg, M. P. (1998). Some conceptions are difficult to change: One middle school mathematics teacher's struggle. Journal of Mathematics Teacher Education, 1, 269.

Wittgenstein, L. (1983). Philosophical Investigations. Oxford: Basil Blackwell.

Zeichner, K. (2010). Competition, economic rationalization, increased surveillance, and attacks on diversity: Neo-liberalism and the transformation of teacher education in the U.S. Teaching and Teacher Education, 26, 1544-1552.

Žižek, S. (1989). The sublime object of ideology. London: Verso.

Žižek, S. (1996). The indivisible remainder: An essay on Schelling and related matters. London: Verso.

Žižek, S. (1998). Four discourses, four subjects. In S. Žižek (Ed.), Cogito and the unconscious. Durham, USA: Duke University Press.

Žižek, S . (2006). The parallax view. Cambridge, MA: MIT Press.

Žižek, S. (2008). Violence. London: Profile Books.

Žižek, S. (2009). Fichte's laughter. In M. Gabriel and S. Žižek (Eds.), Mythology, madness and laughter: Subjectivity in German idealism. London: Continuum.

Žižek, S. (2010). Living in the end times. London: Verso. 